\title{
A ROUGH PATH TOWARDS A THEORETICAL APPREHENSION OF KOREAN ASPECT
}

\author{
Jerzy BAŃCZEROWSKI \\ Poznań College of Modern Languages \\ ban@amu.edu.pl
}

\begin{abstract}
Having considered some general aspectological and aspect-methodological problems, the author proceeds to the discussion of certain selected questions concerning Korean aspectology, in particular, an interaction between aspect and momentarity / progressivity as well as aspective-lingual reasoning. The position of the category of aspect within grammar is revisited of and the problem of formulation of aspectological theories is addressed. The proposed theoretical apprehension of the relation of Korean aspect to momentarity/progressivity and the aspective-lingual deduction are treated rather briefly.
\end{abstract}

Key words: aspect in Korean, category of aspect, momentarity, progressivity

$$
\text { 한국어 상 (相) 의 이해로 가는 험난한 길 }
$$

몇 가지 일반적인 상적 그리고 상적-방법론적 문제들을 검토한 후, 한국어의 상에 관해 특정적으로 선택된 문제들에 대해 논하였다. 특히 상과 일시성/지속성 또한 상과 상적-언어 추론 간의 상호작용에 대해 논하였다. 상에 대한 이론의 공식화의 어려움이 언급되었고, 문법 내에서 상의 범주의 정황을 상기시켰다. 이 논문에서는 한국어의 상과 일시성/지속성 또한 상적-언어 추론 간의 관계에 대한 이론적 이해를 개략적으로 제시하였다.

키워드: 한국어의 상, 상의 범주, 순간성, 지속성 


\section{Introductory considerations}

The current article is a continuation of an aspectological enquiry into Korean initiated in Bańczerowski and Oh (2014). This introductory section is intended to indicate some aspect-theoretical problems related to this language. However, here they shall be approached somewhat differently. The interest in and the curiosity about the Korean aspective reality of the author is hardly accidental, since he, whose native language is Polish, always feels rather uncomfortable, when about to translate a Polish sentence into Korean. In particular, the problem concerns the verbal predicate. The differentiation between the imperfective verbs and the corresponding perfective verbs is deeply rooted in the Polish language consciousness to the extent that during translation one unwittingly seeks Korean translative equivalents in order to adequately render the difference in question. This differentiation is, in Polish, similarly to other Slavonic languages, morphologised to a considerable degree, manifesting itself by means of grammatical morphemes, usually in form of corresponding affixes on the perfective verb.

Aspect in Slavonic languages was recognised in the first half of $20^{\text {th }}$ century as a semantic and grammatical category in its own right, although closely related to the category of time but not subordinate to it (cf. Agrell 1908, Koschmieder 1934, Masłov 1948). Subsequently, it has enjoyed appropriate treatment in grammars of these languages on a par with other grammatical categories (cf. Bogusławski 2003: 24ff). A known fact is that the most verbs inflect here for the dimension of aspect, since the imperfective verbs usually have their perfective counterparts with which they form aspective diacritic pairs the members of which, however, are not always bound by mono-dimensional semantic opposition, that is to say, they are not always opposed exclusively for the dimension of aspect sensu stricto.

The inflection for aspect has been considered as a distinctive peculiarity of Slavonic languages. However, a closer look at other languages, even if they are Japanese or Korean, reveals a comparable inflection, although less grammaticalized, since the significators of Completion may take the form of auxiliary verbs perfectivizing the 
main verbs whereby periphrastic predicates are formed (cf. Bańczerowski and Oh 2014: 52). Thus, the inflection for aspect is found also outside of the domain of Slavonic languages.

Gradually aspect oriented studies of various languages have achieved an appropriate status within linguistic research leading to the recognition that this lingual category, different from time but in close relationship to it, is an indispensable grammatical component. Some even argue, that the aspect may determine the interpretation of tense (Galton 1984:2f).

For an adequate theoretical approximation of aspective reality accessible to a given language community, as well as other realities such as time, modality, diathesis et cetera, it seems necessary to make a clear distinction between the corresponding meanings and their significators. In a certain sense, it should run parallel to a distinction drawn in the grammars of English between the time (temporal meanings) and the tense embracing the corresponding verb forms grouped into paradigms.

The opposition between English verb forms belonging to different tenses as, for example, the past tense versus the present tense or the present perfect tense vs. the present tense is considered to be aspective (cf Galton 1984:2ff). Presumably, the opposition between the present and perfect tenses in Old Greek and Latin was also aspective or at least tinted aspectively.

However, the observations relating to these three languages concern verbal forms, which are opposed not only for the dimension of Aspect but also for the dimension of Time. In the aspective opposition of Slavonic languages primarily homotemporal verb forms are meant, although the allotemporal forms are also bound by it. The homotemporality of such verbal forms makes the aspective opposition more independent from time.

The category of aspect could be understood as the set of all lingual units signifying aspective meanings. One might also say that these meanings specify the category in question, comprised of the aspective significators of various sizes. The aspective meanings, in turn, reflect certain properties of extra-lingual events, that is to say, these aspective properties are conceptualised lingually as aspective meanings. And, furthermore, with respect to the aspective properties, the events enter into the corresponding relationships, which are lin- 
gually conceptualised as aspective relations binding sentences designating these events.

The aspective meanings and the category of aspect, also with the corresponding paradigmatic and syntagmatic relations, including operations, jointly create what is called the aspect or the aspective system, mapping a corresponding fragment of extra-lingual aspective reality. One may also say that this reality is apprehended lingually by native linguators as the aspective system. Consequently, this system appears to be a product and, at the same time, an image projected by lingual conceptualisation of the invoked fragment of extra-lingual reality.

The aspective system may be identified with the aspective code, underlying the aspective coding or simply the code in use, which manifests itself as the co-operations of encoding and decoding. Having acquired the aspective code enables one thus to perform these two operations. The former provides for the construction of aspectively correct sentences, and the latter for their understanding and the evaluation of their correctness.

The conspicuity of the aspective system in language consciousness of native linguators is certainly fortified by such factors as the following:

(i) the mono-dimensional aspective opposition (vs poly-dimensional aspectual opposition);

(ii) the aspective auto-significators (vs aspective syn-significators);

(iii) strong grammaticalisation of the aspective significators (vs weak one), and

(iv) lexical aspective determinacy (vs indeterminacy).

Events are not only characterisable in relation to the dimension of Time, that is, with respect to their location on the temporal axis but also with respect to the modes of their course through time. These modes of temporal course of events are accountable in the aspectual space specified by the dimensions of Aspectuality, one of which is just the dimension of Aspect. The aspective apprehension of events, as completed, incompleted or aspectively indeterminate, does not thus exhaust their aspectual diversity. Among other dimensions, by which aspectual space is shaped, the following may be distinguished:

(i) Plicativity (Semelfactivity, Iterativity (Many-times-ness) ), and 
(ii) Length of time (Momentarity, Duration (Progressivity, Continuity) ).

The events develop simultaneously relative to various dimensions in a multidimensional aspectual space, and relative to these dimensions they interact appropriately. Thus, the Aspect is not independent from other aspectual dimensions.

The divergence between the aspective systems of languages may affect the aspectological communication, of which linguists may not always be aware (cf. Galton 1984: 16). This article is written in English, it will discuss certain aspective phenomena of Korean, and the native language of the author is Polish. The aspective systems of these three languages are far from being aspectively convergent and the aspective distances between them have not yet been determined. The image of the aspective reality emerging from the argumentation formulated here in English will of necessity not completely coincide with the images emerging from the corresponding argumentations formulated in Korean or Polish. All three argumentations will differently approximate the reality in question. And, what is worse, it is almost impossible to decide whether one of these images is more adequate than the others since no person possessing sufficient and simultaneous aspective competence in these three languages exists.

It should be remembered that within aspectology, or the science of aspect, a general and particular as well as pure and applied could be distinguished. The general aspectology applies to all languages whereas the particular one, in addition to panglottally valid principles, should operate also with such ones, which apply predominantly to a particular language in order to reflect its aspective peculiarity. Within both pure and applied aspectology, in turn, a theoretical and practical should be recognised as distinct (cf. Bańczerowski and Oh 2014: 45). 


\section{For the sake of methodological clarity}

As has been mentioned in Bańczerowski and Oh (2014: 42) the literature on aspect is enormous. The inquiry into the aspective realities of some languages is relatively advanced, and the collected relevant lingual data are impressive. The knowledge being gained about aspect has been presented in various ways by aspectological theories, depending on how they are formulated. Not infrequently they display obscurities and turbidities, not to speak of their formal flaws. Such deficiencies may concern the adopted terminology, the theorems or the definitions. In consequence, the comprehension of the content of a proposed theory may be negatively affected, causing a superfluous discussion. Thus, the situation in theoretical aspectology may not be viewed as satisfactory, and referring to philosophical foundations, in particular to methodological ones, could help to deepen insight into the aspectological enterprise.

The theoretical aspectology can be considered as a class of various linguistic theories, the subject matter of which is the aspective or aspectual reality (cf. Bańczerowski and Oh 2014: 45). And furthermore, one and the same lingual reality or its fragment can be inquired into in innumerable ways, yielding the corresponding theories. Obviously, this also applies to the aspective reality, which can be approximated by a multitude of various theoretical solutions.

Generally speaking, an aspectological theory may be imagined as a kind of deductively connex text, encoding by means of asserted statements a fragment of knowledge about aspective reality being its subject matter, with the purpose to describe and explain it. As can be rightly inferred, such a theory is formulated with the intention to deliver true statements about the subject matter in question, the image or representation of which, projected by this theory, can be referred to as a model or domain, usually conceived of as a system consisting of lingual objects and relations.

The methodology of aspectology, derived from an appropriate restriction of the field of linguistic methodology, emerges as a science of the methods of the formulation and justification (substantiation) of aspectological theories. In coding the aspectological knowledge, these 
theories must use some language, natural or artificial, which may be formalised to a varying degree. Whether the image of this knowledge depends on the degree of formalisation of the theory's language, will be left undecided here.

Hitherto, most aspectological theories have been formulated in an ordinary rather than a formal language. The aspiration after the formalisation of linguistic theories reflects a drive towards ensuring precision of the formulation of these theories whereby the indicated deficiencies could be avoided.

Thus, theoretical aspectology as a subfield of theoretical linguistics cannot abandon the escape from imprecision, and on the way towards perfecting the formulation of its theories it should also make efforts to axiomatise them. In an axiomatic linguistic theory, at least the following three components should be present: (i) the terminological (conceptual), (ii) the propositional, and the explanatory. By virtue of precise determination of these components, the application of the axiomatic method secures the most advanced formulation of the theories in question. The theoretical aspectology has already attained an appropriate stage in its development whereby aspectological theories are susceptible to logical reconstruction and subsequent axiomatisation.

Within theoretical aspectology it seems reasonable to discuss the relationship between the intuitive aspective knowledge or aspective consciousness of the linguators and the aspectological knowledge of the linguists. This latter reflects thus a metalingual apprehension of the former. However, the adequacy of the aspectological description or approximation of the intuitive aspective knowledge should find a confirmation in its empirical appearances, that is, in the lingual practice, particularly, in the linguators' ability to decide on the correctness of certain compound aspective sentences. Such a decision is made possible, because it is based on the knowledge of the corresponding aspective system or, simply, the grammar, which determines the necessary conditions for aspectively correct utterances, and which operates within the language consciousness.

Thus, in the case of Aspect one would be considering two kinds of knowledge:

(i) aspective-lingual, and

(ii) aspective-metalingual (aspectological, linguistic). 
The former, being intuitive, is accessible to direct cognition or sensed directly, and can be acquired properly only by native linguators, whereupon it always is at their prior disposal. The latter, in turn, is intellectual, results from indirect cognition and is a product of linguistic inquiry. In a certain sense, the aspectological knowledge specifies an image (model) for the aspective-lingual knowledge, an image projected by a corresponding aspectological theory. Consequently, the grammar of aspect may be understood in a two-fold way, that is, either as:

(i) an aspective-lingual grammar, imagined in the form of a system of respective matrices coding the intuitive aspective knowledge and necessary for the reproduction and recognition of aspectively correct utterances, or as:

(ii) an aspectological grammar being a theory about the corresponding intuitive aspective knowledge. However, one and the same aspective lingual grammar can be approximated by diverging aspectological grammars.

Analogously, one could perhaps distinguish two types of logic. The aspective-lingual logic, in operation within an aspective-lingual grammar, would underlie the decisions of native linguators made on aspective correctness. And, in turn, the aspectological logic could be understood as a theory for the language of aspectological grammars or, putting it differently, for the scientific language of Aspect.

In Bańczerowski \& Oh (2014) some attention was devoted to the acceptability of aspectively adversative and conditional sentences. The acceptability in question presupposes a prior decision on aspective correctness which, in turn, depends on various kinds of lexical and grammatical connexity. Ultimately, this decision is thus based upon the aspective knowledge determining the necessary conditions for the correctness at issue.

However certain aspectively conditional sentences are not correct or at least their correctness is dubious. Subsequently some such sentences shall be considered against the dimension of Momentarity / Progressivity in this respect. 


\section{Aspective Relativity}

Aspect as a lingual category seems to be relative, in the sense that it enters into a relationship with other lingual categories, in particular with aspectual ones. Although the aspective dimensions and meanings, which specify the corresponding aspective categories, seem to be absolute, it should be borne in mind that the absolute reality is inseparable from the relative one. The combination of the aspective meanings with other aspectual ones should find appropriate reflection in the significators, which convey such composite meanings. Before proceeding to the discussion of the interaction between these significators, attending to certain particulars, some of which concern the ontology of events, is advisable.

A kind of conditional subordination is represented in Korean by aspective compound sentences in which a perfective sentence as protasis is subordinated by means of conjunction (만약 manyag) ... -면 myeon 'if, then' to a corresponding perfective or aspectively indeterminate subsentence as apodosis. A sizeable set of such compound sentences designating durative events are correct and judged as acceptable, which implies they are both sensical and true. And, this statement is confirmed among many other Korean sentences by the following:

만약 그가 자기 집을 지어 버렸다면, 그는 그의 집을 지었다. Manyag geu-ga jagi jib-eul jieo-beoryeotta-myeon, geu-neun geu-eui jib-eul jieotta.

'If he finished constructing his house, then he was constructing it.'

'Jeśli zbudował swój dom, to go budował.'

(3.2) 만약 그가 자전거를 사 두었다면, 그는 자전거를 샀다.

Manyag geu-ga jajeongeo-reul sa-dueotta-myeon, geu-neun jajeongeo-reul satta.

'If he bought a bicycle (just in case), then he was buying it.'

'Jeśli kupił rower (na wszelki wypadek), to go kupował.' 
It should be noted that in the above aspectively conditional Korean sentences, the perfective sentence is not interchangeable with the respective imperfective one, since such an interchange would result in a non-sensical and hence an aspectively unacceptable sentence.

For the sake of directing the course of the subsequent discussion, the formulation of the following hypothesis is rather expedient.

Hy 3.1. The acceptability of an aspectively conditional sentence, the protasis of which designates a completed durative event, presupposes a conception of this event as incorporating an incompleted sub-event occurring prior to the completion of the former.

However, the lingual conceptualisation of certain completed events does not unambiguously permit a decision whether they can incorporate corresponding incompleted sub-events or not (cf. 쓰러지다 sseureojida 'to fall over'). This problem appears, when Completion is signified in combination with the aspectual meaning of Momentarity.

The momentary-proper event can be conceived of as instantaneous, that is to say, lasting only for an instant. The time of occurrence or termination of such an event almost immediately succeeds the time of its begining. In consequence, its termination seems to almost coincide in time with its inception. And, furthermore, such an event is felt always as completed, while inherent in it a progressive incompleted subevent seems practically ungraspable. If such an approach to the conceptualisation of momentary-proper events is adequate, then it should find an appropriate lingual reflection. In other words, the apprehension of momentary-proper events as non-progressive and hence non-durative or, more precisely, as minimally durative, should be confirmed by lingual expressions.

A progressive event is durative and incompleted. Having nonminimal duration, its instantaneousness is excluded, and its nonmomentariness easily prehensible. What is more, the termination of a progressive event does not entail its completion. In Korean, the meaning of Progressivity is signified morphologically by a corresponding progressive construction, that is, a compound verb-form functioning as a minimal syntactic unit, which might be called a syntactic word or 
tagmon, and is constituted of the auxiliary 있다 itta 'to be' linked to a verb-stem augmented by suffix -고 $-g o$.

The above brief chacterisation of momentary and progressive (continuing) events, in respect to a proposed distinction in their conceptualisation, can be captured more precisely in terms of the following tentative postulates referring thus to the ontology of events and their lingual apprehension.

Po 3.1. The inception of a momentary-proper event precedes its termination by a negligible space of time, that is, an instant.

Po 3.2. From a mereological point of view, a momentary-proper event can be treated as its only sub-event.

Po 3.3. Every momentary-proper event is conceived of as completed.

Po 3.4. The time limits of the course of a progressive event may be either determined or left undetermined. Putting it differently, such an event may be temporally closed or open.

Po 3.5. Every event, apprehended lingually as progressive (continuing) that is, designated by a progressive form of a predicate, is conceived of as incompleted or aspectively indeterminate, irrespective of its having terminated or not.

Po 3.6. Within a completed durative event a progressive sub-event tending towards completion necessarily obtains.

Po 3.7. A simple progressive event does not incorporate any completed sub-event.

Po 3.8. No simple event can be simultaneously momentary-proper and progressive, that is to say, neither a momentary-proper event can be progressive, nor can a progressive event be momentary-proper. Thus, Momentarity-proper and Progressivity are mutually exclusive as properties of the same simple event.

Po 3.9. A momentary-iterative compound event is constituted as a sequence (chain) of momentary events. Such a compound event itself may be completed or incompleted.

Po 3.10. A progressive form can be derived both from durative verbs and nomino-verbal constructions.

Po 3.11. If an aspectively conditional sentence designates a sequence of momentary sub-events within a compound event then it signifies Momentarity and Iterativity at the same time. 
Po 3.12. Within the same aspectively conditional sentence, the protasis signifying Momentarity-proper of an event is not connex with an apodosis signifying Incompletion of this event. However, if the apodosis signifies Completion, the resulting sentence might be regarded as an aspective quasi-tautology.

Thus, with the above postulates in mind, the subsequent argumentation is intended to indicate a distinction between lingual conceptualisation of durative and progressive events, on the one hand, and momentary events, on the other. Some compound aspective sentences with the predicate-forms derived from the verb 읽다 ilgda 'to read' and those derived from the nomino-verbal construction 재채기하다 jaecaegi-hada 'to sneeze' will be examined. The former predicateforms will signify Durativity or Progressivity, and the latter Momentarity.

The accomplishment of the task would be facilitated, if one could compare exhaustive aspective sentential paradigms, constructed for these predicates (cf. Bańczerowski \& Oh 2014: 52). The paradigms of this kind could be comprised of conditional and adversative sentences inflecting for aspectual, among them aspective, dimensions. However, constructing such paradigms is hardly feasible, at least for the time being. Therefore we shall only avail ourselves below of certain sentences belonging to the paradigms in question, hoping to partially reflect also upon the relational status of aspectivity within aspectuality by which the aspect in a broader sense (Aktionsart) is meant.

It is now time to proceed to the analysis proper which will begin with the following sentence:

만약 그가 재채기하고 있었다면, 그는 한 번 또는 서너 번 재채기해 버렸다.

Manyag geu-ga jaecaegi-hago-isseotta-myeon, geu-neun han beon ttoneun seoneo beon jaecaegi-hae-beoryeotta.

'If he was sneezing, then he sneezed once or several times.'

'Jeśli kichał / był w trakcie kichania, to kichnął raz lub kilka razy.'

This sentence, with the protasic predicate 재채기하고 있었다 jaecaegihago-isseotta 'was sneezing' is acceptable to native Koreans. On the 
contrary, a sentence (3.4) constructed analogously to (3.3), but with the protasic predicate 읽고 있었다 ilg-go-isseotta 'was reading' is unacceptable, and evidently non-sensical.

$$
\begin{aligned}
& \text { *만약 그가 이 책을 읽고 있었다면, 그는 이 책을 한 번 또는 } \\
& \text { 서너 번 읽어 버렸다. } \\
& \text { *Manyag geu-ga i caeg-eul ilg-go-isseotta-myeon, geu-neun } i \\
& \text { caeg-eul han beon ttoneun seoneo beon ilgeo-beoryeotta. } \\
& \text { *'If he was reading this book, then he read it once or several } \\
& \text { times.' } \\
& \text { *'Jeśli czytał tę książkę / był w trakcie czytania tej książki, to } \\
& \text { ją przeczytał raz lub kilka razy.' }
\end{aligned}
$$

Thus, in (3.3) a progressive imperfective predicate phrase in protasis is connex with a semelfactive-iterative perfective predicate phrase in apodosis. In turn, (3.4) shows that such a connexity is impossible. Consequently, the unacceptability of (3.4) is in agreement with Po 3.7, which excludes the possibility of existence of a completed subevent within a corresponding progressive event. And (3.3) seems apparently to run counter not only to Po 3.7 but also to Po 3.8. The explanation for this situation is offered by Po 3.9, under the condition that sentence (3.3) is interpreted as designating a sequence of momentary and thereby completed events of sneezing, except the last incompleted member of this sequence. On this assumption Progressivity refers to the whole sequence, while Momentarity refers to its particular members with the exception of the last, and such an interpretation conforms to Po 3.11. Thus, in spite of the particular subevents being completed, the sequence as a whole may not attain completion, which is evidenced by the following sentence:

만약 그가 재채기하고 있었다면, 그는 한 번 또는 서너 번 재채기했다 혹은 재채기를 다 해 버리지 않았다.

Manyag geu-ga jaecaegi-hago-isseotta-myeon, geu-neun han beon ttoneun seoneo beon jaecaegi-haetta hogeun jaecaegireul da hae-beoriji-anatta.

'If he was sneezing, then he sneezed once or several times or did not sneeze completely (although he felt such a need).' 
'Jeśli kichał / był w trakcie kichania, to kichnął raz lub kilka razy bądź się całkowicie nie wykichał (chociaż czuł taką potrzebę).'

Similarly to (3.3) sentence (3.5) is also acceptable. Thus, although the sequence of particular completed events of sneezing terminated, this compound event did not reach an intended completion.

In line with our expectations, sentence (3.6) constructed analogously to (3.5) is rather unacceptable.

*만약 그가 이 책을 읽고 있었다면, 그는 이 책을 한 번 또는 서너 번 읽어 버렸다 혹은 다 읽어 버리지 않았다.

*Manyag geu-ga i caeg-eul ilg-go-isseotta-myeon, geu-neun $i$ caeg-eul han beon ttoneun seoneo beon ilgeo-beoryeotta hogeun da ilgeo-beoriji-anatta.

*'If he was reading this book, then he read it once or several times or did not read it entirely.'

*'Jeśli czytał tę książkę / był w trakcie czytania tej książki, to ją przeczytał raz lub kilka razy bądź nie przeczytał jej całej.'

The dubious unacceptability of sentence (3.6) is consequent upon the lack of connexity between the durative-progressive predicate of protasis and the corresponding affirmative-perfective predicate of apodosis. However, the protasis of (3.6) is connex with the negative-perfective predicate of apodosis (cf. Po 3.5). Thus, one could say that the protasis of this Korean sentence does not entail the first predicate phrase of the apodosis, but it entails the second predicate phrase of the apodosis.

Let us still inspect the following aspectively adversative sentence:

그가 재채기하고 있었지만, 그러나 그는 재채기해 버리지 (는) 않았다.

Geu-ga jaecaegi-hago-isseott-jiman, geureona geu-neun jaecaegi-hae-beoriji (neun) -anatta.

'He was sneezing, but he did not sneeze entirely.'

'Kichał / był w trakcie kichania, ale się całkowicie nie wykichał.' 
The acceptability of sentence (3.7) is not objectionable, since there obtains a connexity, based on sense, binding the affirmative progressive predicate of the antecedent, signifying Momentarity-Iterativity, with the negative-perfective predicate of the succedent, signifying Incompletion. However, if the predicate of the antecedent in this sentence would be interpreted as designating a momentary-semelfactive event, this sentence would appear unacceptable (cf. Po 3.3 and Po 3.11).

For the sake of comparison let us also adduce sentence (3.8) with the predicate being a progressive form of the verb 읽다 ilgda 'to read.'

그가 이 책을 읽고 있었지만, 그러나 그는 이 책을 읽어 버리지 (는) 않았다.

Geu-ga i caeg-eul ilg-go-isseot-jiman, geureona geu-neun $i$ caeg-eul ilgeo-beoriji (neun) -anatta.

'He was reading this book, but he did not finish reading it.'

'Czytał tę książkę / był w trakcie czytania tej książki, ale jej nie przeczytał.'

As may be expected, this sentence, similarly to (3.7) is also acceptable (cf. Po 3.5).

By way of concluding this section, it is worth remembering that it has been intended to show some of the distinctions and similarities in the lingual conceptualisation of momentary and durative events in the aspective perspective, while availing oneself of the predicates derived from the verb 읽다 ilgda 'to read' and the hybrid nominoverbal construction 재채기하다 jaecaegi-hada 'to sneeze'. The progressive forms of these predicates proved to be particularly important for the comparison being performed. Some of the postulates being formulated above may prove to be inadequate in the course of a subsequent, further and more thorough research. In such a case they should be accordingly corrected 


\section{Aspective Lingual Reasoning (Deduction, Concluding)}

The aspective knowledge of linguators, as a component of their lingual knowledge, underlies lingual reasoning or deduction being performed within a given language community. Based on their intuitive aspective knowledge, that is aspective grammar, linguators are able to make decisions on aspective correctness of sentences. Thus, they know in advance, which conditions the sentences should satisfy, in order to be aspectively correct. A sentence being aspectively correct is subsequently appraised for its acceptability in a given communicative situation. Consequently, it may be said that the decision on correctness presupposes grammatical competence, and the decision on acceptability presupposes pragmatic competence. If a Korean hears a sentence

선생이 교실 문을 열어 버렸다.

Seonsaeng-i gyosil mun-eul yeoreo-beoryeotta.

'The teacher opened the door of a classroom.'

'Nauczyciel otworzył drzwi klasy.'

and if the communicative situation does not provide information on why the teacher did so, he immediately deduces that this teacher opened the classroom door for some reason, as for instance, it could be overly stuffy inside. This kind of deduction is forced upon the hearer by the predicate 열어 버렸다 yeoreo-beoryeotta, in particular, by the perfectisising auxiliary, in this case 버렸다 beoryeotta, which also conveys some modal information

Sentence (4.1) also enables deducing the following aspectively conditional sentence:

선생이 교실 문을 열어 버렸다면, 그는 교실 문을 열었다.

Seonsaeng-i gyosil mun-eul yeoreo-beoryeotta-myeon, geuneun gyosil mun-eul yeoreotta.

'If the teacher opened the door of a classroom (for some reason), then he was opening / opened it.'

'Jeśli nauczyciel otworzył drzwi klasy (z jakiegoś powodu), to on je otwierał / otworzył.' 
The fragment of Korean lingual knowledge, on which the correctness of the aspectively conditional sentence of type (4.2) is based, can be approximately reflected by the following postulate proposed for the testing of the correctness in question.

Po 4.1. If $s$ is an aspectively conditional sentence consisting of protasis $p$ an apodosis $q$, and such that the predicate of $p$ is perfectisised by a corresponding auxiliary verb, and the predicate of $q$ is imperfective or aspectively indeterminate, and both $p$ and $q$ are affirmative homolexical sentences, then $s$ is aspectively correct.

This postulate specifies a class of sentential schemata for the corresponding Korean aspectively correct conditional sentences. What is more, this postulate, as a general statement, seems also necessary for aspective explanation being a kind of explanative deduction (cf. Ajdukiewicz 1964). Aspectological theories, as has already been mentioned above, are formulated with the purpose to deliver not only sheer descriptions of aspective reality but also explain individual (singular) aspective facts.

The explanation in aspectology can avail itself of the explanation scheme in order to deduce answers to the questions such as for example: Why a given aspectively conditional sentence is correct? Without going into details here, one may say that sentence asked about, if it fulfills the conditions specified by the antecedent of postulate 4.1, then it compellingly also fulfils, in a certain sense the succedent of this postulate, which is, it is of necessity correct. Thus, since the sentence (4.2) fulfils the antecedent of postulate 4.1, then it also fulfils the succedent of this postulate.

To test the hypothesis asserting that Korean verbs are aspectively indeterminate, let us consider the following sentence:

그는 편지를 썼다.

Geu-neun pyeonji-reul sseotta.

'He was writing / wrote a letter.'

'On pisał / napisał list.' 
If this hypothesis is true, and if the communication situation does not eliminate the aspective vagueness of (4.3), then it should be possible to deduce from it the following conclusions:

그는 편지를 썼지만, 다 안 썼다.

Geu-neun pyeonji-reul sseot-jiman, da anseotta.

'He wrote a letter, but he did not write it entirely.'

'Pisał list, ale go nie skończył.'

그는 편지를 썼고, 그리고 그것을 다 썼다.

Geu-neun pyeonji-reul sseot-go, geurigo geu geos-eul da sseotta.

'He was writing a letter and finished it entirely.'

'Pisał list i go napisał.'

그는 편지를 썼는데, 그것을 다 썼다.

Geu-neun pyeonji-reul sseonneunde, geu geos-eul da sseotta.

'He was writing a letter and finished it entirely.'

'Pisał list i go napisał.'

Thus since sentences (4.4) - (4.6) are acceptable as conclusions inferred from (4.3), they seem to confirm its aspective equivocality.

\section{Concluding Remarks}

Arriving at the end of our aspectological deliberations it cannot be said that our objections to the theoretical framework, applied in this article, vanished as if by waving a magic wand. Just the contrary, they do persist and the author has a sneaking suspicion that he has created a virtual aspective reality whose distance to the real one is still considerable. Nevertheless, the theoretical proposal, which we have been concerned to outline (cf. also Bańczerowski \& Oh 2014) may prove to be one of the possible approximations to Korean aspective reality, at best. This reality may be described by various theories offering in 
consequence various alternative models. Furthermore, such alternative descriptions justify speaking of an aspectological relativity different from the aspective relativity, since the former applies to the diversity of aspectological theories illuminating the aspective reality from different angles and thus projecting their corresponding different images as models, whereas the latter considers the status of the Aspect relative to other aspectual categories.

Most of the Korean sentences considered above are rather artificial, hardly used in real communication, but they may be judged for correctness by native linguators, and their judgments will be true of necessity, since they are made on the basis of intuitive lingual knowledge. This knowledge is encoded as lingual grammar, a fragment of which is an aspective grammar being operated by an aspective logic. Hence the distinction between an aspective grammar and an aspectological grammar should be obvious, the latter being in fact a theory describing aspective knowledge by means of an artificial metalanguage, operated by a metalingual knowledge (cf. modern formal logic).

\section{Bibliography}

Abraham, Werner; Kulikov, Leonid. (eds), 1999. Tense-aspect, transitivity and causativity: essays in honor of Vladimir Nedjalkov. Amsterdam/Philadelphia: John Benjamins Publishing Co.

Ajdukiewicz, Kazimierz. 1964. Dowód i wyjaśnianie. Szkice filozoficzne Romanowi Ingardenowi $w$ darze. Warszawa-Kraków: PWN, 211-220.

Bańczerowski, Jerzy; Grzelak, Szymon. 2012. Translational quandaries and suggestions, Folia Orientalia 49, 41-55.

Bańczerowski, J.; Oh, Kyong-geun. 2014. A draft proposal for a theory of aspect in Korean. Rocznik Orientalistyczny LXVII, 42-54.

Binnick, R.J. (ed.). 2012. The Oxford handbook of tense and aspect. Oxford: Oxford University Press.

Bogusławski, Andrzej. 2003. Aspekt i negacja. Warszawa: Katedra 
Lingwistyki Formalnej.

Bogusławski, Andrzej. 2005. A note on the aspectual retarder in English-Russian and English-Polish translation. In: Stanulewicz, D.; Kalisz, R.; Kürschner, W.; Klaus, C. (eds.). 2005. De lingua et litteris. Studia in honorem Casimiri Andreae Sroka. Gdańsk: Wydawnictwo Uniwersytetu Gdańskiego, 399-406.

Byon, Andrew Sangpil. 2010. Intermediate Korean. A grammar and workbook. Abingdon: Routledge.

Chang, Suk-jin. 1973. Some aspects of aspect: duration and completion. Language Research 9.2 (in Korean).

Chang, Suk-Jin. 1996. Korean. Amsterdam: John Benjamins Publishing Co.

Chung, Kyung-Sook. 2012. Space in tense: the interaction of tense, aspect, evidentiality, and speech acts in Korean. Amsterdam/Philadelphia: John Benjamins Publishing Co.

Comrie, B. 1976. Aspect. An introduction to the study of verbal aspect and related problems. Cambridge: University Press.

Czarnecki, T. 1998. Aspektualität im Polnischen und Deutschen. Gdańsk: Uniwersytet Gdański.

Dahl, Östen 1985. Tense and aspect systems. Oxford: Basil Blackwell.

Forsyth, J. 1970. A grammar of aspect. Usage and meaning in the Russian verb. Cambridge: University Press.

Galton, A. 1984. The logic of aspect. An axiomatic approach. Oxford: Clarendon Press.

Holvoet, A. 1989. Aspekt a modalność w języku polskim na tle ogólnostowiańskim. Wrocław: Ossolineum.

Ihm, Ho Bin; Hong, Kyung Pyo; Chang, Suk In. 2001. Korean grammar for international learners. Seoul: Yonsei University Press.

Karolak, S. (ed.). 1995, 1997. Semantika i struktura slavjanskogo vida. I-II. Kraków: Wydawnictwo Naukowe WSP.

Kholodovič, A.A. 1954. Očerk grammatiki korejskogo jazyka. Moskva: Izdat'el'stvo lit' eratury na innostrannyx jazykax.

Kim, Eun-Hae. 2009. A comparative study of the progressive aspect: Czech \& Slovak languages vs. Korean \& Japanese languages. Исследованиа по славянским яыкам 14.1, 97-106.

Kim, Jong-Bok. 2011. Ambiguities in the Korean -KO ISSTA imperfective construction. Korean Journal of Linguistics. 36.4, 863-885. 
Kim, Sung Hwa. 1990. A study of aspect of present-day Korean language. Seoul: Hanshin Publishing.

Kim, Won Bo. 2011. An analysis of English tense and aspect errors in Korean-English translation. Beonyeokhak Yeongu 12.4, 231-262.

Kim-Renaud, Young-Key. 2009. Korean. An essential grammar. New York: Routledge.

Lee, Chungmin. 1982. Aspects of aspect in Korean. Linguistic Journal of Korea. 7:2. 570-582.

Mehlig, H.R. 1998. Aspekt, Negation und referentieller Status verbaler Prädikationen. Slavische Linguistik 1997. München: Sagner, 123-142.

Młynarczyk, Anna. 2004. Aspectual pairing in Polish. Utrecht: LOT Publishing.

Mun, Suk-Yong. 2009. Hangugeo-eui sijebeomju. Seoul: Taehaksa.

Ono, Tsuyoshi. 1992. The grammaticalisation of the Japanese verbs oku and shimau. Cognitive Linguistics. 3.4, 367-390.

Park, Jin-Ho. 2011. Tense, aspect and modality. Gugeohak 60.4, 289422.

Pultr, Alois. 1960. Lehrbuch der koreanischen Sprache. Halle (Saale): VEB Max Niemeyer Verlag.

Ramchand, G. C. 2008. Perfectivity as aspectual definiteness: Time and the event in Russian. Lingua 118, 1690-1715.

Rhee, Seongha. 2008. At the borderland of lexis and grammar: Grammaticalizing perfective markers in Korean. Discourse and Cognition 15.3, 29-59.

Schwenk, H.-J. 2007a. Flexion oder Dervation. Zum Status der Aspektkategorie im slavischen Sprachsystem und angrenzende Probleme. In: Grucza, S. (ed.). 2007. W kręgu teorii i praktyki lingwistycznej. Warszawa, 281-309.

Schwenk, H.-J. 2007b. Aspekt, Aktionsart und deverbale Derivation: Morphologie ein Gradmesser für aspektuelle Paarigkeit? Kwartalnik Neofilologiczny 1, 26-55.

Sohn, Ho-Min. 1999. The Korean language. Cambridge: University Press.

Sohn, Sung-Ock S. 1995. Tense and aspect in Korean. Honolulu: University of Hawaii.

Sommers, Fred. 1982. The logic of natural language. Oxford: Clarendon Press. 
Sørensen, F. (ed.). 1986. Aspects of aspect. Three studies on aspect in English, French and Russian. Copenhagen: Busck.

Szwedek, A. 1998. Dokonana interpretacja niektórych polskich czasowników niedokonanych: współdziałanie leksykonu, gramatyki i tekstu. Studia Linguistica Polono-Meridianoslavica 9, 61-68.

Verkyul, H. J. 1972. On the compositional nature of the aspects. Foundations of Language Supplementary Series vol. 15, Dordecht: D. Reidel.

Yang, In-seok. 1977. Progressive and perfective aspects in Korean. Eoneo (Language). 2.1, 25-40. 